\title{
THE INFLUENCE OF EASE OF USE AND FACILITATING CONDITION ON INTENTION TO ACCEPT E-LEARNING PLATFORM
}

\author{
Haifa Yaqoot Almusheifri \\ College of Commerce and Business Adminstration, \\ Dhofar University
}

\begin{abstract}
The topic has been selected regarding to recent dramastic change in education all over the world. In this research, the aim is to determine the level of acceptance of e-learning specifically by the students as well as identifying the effect of ease of use and facilitating conditions on the intention of students to accept e-learning platforms. Primary data was collected using online questionaire, only 118 responses were valid for analysis. The measrement items for the variables were adopted from validated instruments and published articles and books used as a secondary source for getting data for this study. An appropriate statistical analysis tests were used to check the instrument reliability (Cronbach's alpha) and testing research hypotheses (multiple linear regression test). To get this statistical test done the SPSS software was used.
\end{abstract}

Keywords - Ease of Use, Facilitating Condition, Intention to Accept E-learning Platform.

\section{INTRODUCTION}

The e-learning platform or model is a new channel for acquiring education [1]. Also, It can be defined as a virtual place where students can learn instead of a traditional way [2]. There are many universities all over the world that offer these services to students for the learning process simple and very easy. However, there are some barriers to make an effective implementation of the e-learning system. In some of the positives that save time and effort, low costs, easy return to the scientific topic, and for the negatives, there are many who face difficulties in accessing the educational platform and other technical problems [3].

There are many factors that affect quality of elearning. Such as user satisfaction, system quality and the quality of the information provided [4]. There are five basic principles for quality of distance education, accessibility, feasibility, education, student and teacher satisfaction, and unforgettable economic viability [5]. The most important pillar of e-learning is the user. According to: Lang; Kysel (2019) the main issue of e-learning is that this system doesn't have the methods, procedures and techniques that enable students to define the information, concepts and skills that one should be able to provide.

According to Verkhova, Akimov (2019) using of qualimetric models in e-learning systems is very crucial to represent the academic accomplishments and comprehensive assessment of e-learning quality. According to Soukaina, El Bouhdidi, El Younoussi, Carrillo (2019) to develop learning tools we have to focus on web based engineering education which leads to build a very effective system[6]. According to Hilmy, De Silva, Pathirana, Kodagoda, Suriyawansa, (2019) the massive open online course is considered as a main source of e-learning materials[7]. According to Serhii, Volodymyr, Nataliia, Andrii (2019) that the (ADS) which is axiomaticdeductive strategy is very important in organizing the elearning course. Moreover the ADS satisfies the requirements for e-learning course semantic quality.

According to Naveed, Ahmad, Qamar, Khan, Naim, Hussain, Qureshi, Alsayed, Mohiuddin (2019) e-learning system provides a chance to get knowledge in most effective manner. The authors added that including the online social networking is very helpful in order to develop e-learning process and make it wider and effective [8].

The online social media tools is very important in improving and enhancing the e-learning system. It will make it easier and flexible for the students [9]. Vagarinho, LlamasNistal (2019) suggests universities that providing e-learning system should have a competitive advantage to attract students to them[3]. This can by enhancing the rules and policies that are implemented by these universities. The global model can be implemented from different universities all over the world that give students enough time to select the best e-learning system offered by colleges or universities. This point influences the building of e-learning system. Since each university is asked to improve an effective system that make students select them among different universities. Burdi, Chandio, Abbasi, Abbasi, Naqvi (2019) show that it is very necessary focusing in building an advanced model for elearning system [10]. This will enable users to access very easily and without any confusion. So and according to the author, the web designers should not forget any point while developing the system. Soukaina, El Bouhdidi, El Younoussi, 
Carrillo, (2019) think that to develop learning tools we have to focus on web based engineering education to build very effective system [6]. These two articles are forcing on same point, which are building a dynamic system for e-learning that contain all the need of users is very important.

There is a need for building a system which includes all the aspects of a successful website like the content, context, customizing, communication, screen design and the other components that allow the users view the online system comfortably. According to Souali, Rahmaoui, Ouzzif, El Haddioui, (2019) it is very difficult to advise the most suitable educational resources for educators and researchers. The authors think that using Artificial Intelligence can help them to overcome this problem [11]. According by Naim, Hussain, Naveed, Ahmad, Qamar, Khan, Hweij (2019) that e-learning have two main challenges which are the interoperability of elearning and developing learning through e-learning [9]. The both authors are talking about the challenges and difficulties that face the proper implementation of e-learning system. At the first article, the author believes that selecting the right eleaning system is very complex topic.

While at the second article, the authors thinks that the interoperability is the main issue in developing e-learning system. Whatever, electronic learning (e-learning), like other e-commerce application, still not investigated sufficiently. In the context of the study the adoption of technology has been investigated by few research, work process digitalization[12], providing e-government services [13], [14], accepting E-Mail System University Students[15], Clients acceptance of Internet Banking[16], adopting ICT by SMEs employees [17], and customers attitudes to adopt e-shopping [18]. Moreover, from the teaching assessment perspective also few studies has been done in the context of the study[19]

In brief, e-learning system is a new technology for introducing and providing the education for the learners. Any new technology launched will face difficulties and challenges in the beginning. People will not accept it till they got full understanding of it. E-learning system need to be dynamic and flexible for the users. Moreover, it needs to apply the latest elearning tools to make the learning easy for the users. In addition, the e-learning system should connect to social media networking to facilitate the usage the learning process for the learners and wide the channels of communication between the whole users. Most of authors agree that e-learning system faces some challenges and the educational institutions that take online learning as another way for learning, should work hard to overcome these barriers by developing polices and learning tools.

\section{LITERATURE REVIEW}

TAM stands for Technology Acceptance Model; this theory is considered with the user's acceptance for a new technology or system. It models how users adopt or use the technology. The technology acceptance model has been adopted widely to study the needs of users for any new technology[20].

UTAUT is a modern technology that has been developed to facilitate the usage of technology for the users. UTAUT stands for Unified Theory on Acceptance and Use of Technology[21].

1.1 Facilitating condition: the implementing of condition that achieve the target of such thing[22], [23]. Ugandan universities used facilitating condition to make best use of elearning implementation based on the UTAUT model. Ugandan universities were trying to study and establish the facilitating conditions that allow e-learning to prevail amongst these institution of learning. The Ugandan universities used facilitating conditions to determine behavior intention to use a technology. They focused on financial resources infrastructure, human resource and conditional content as facilitating condition to implement e-learning. The final output of this paper are the antecedents of facilitation condition that must be quantitatively or qualitatively tested to prove their contribution in facilitating the adoption and utilization of elearning [24]. Many Universities study the factors that influence the students accepts of e-learning. As a result, researchers should take into consideration both technological and learning expectancies of students while investigating elearning acceptance. There are four primary factors that affect the acceptance of e-learning by the student, which are performance expectancy and effort expectancy, social influence and facilitating conditions. The findings of this study show that both technological expectancy and educational compatibility are important determinants of e-learning acceptance [25]. Another study discovered the key drivers of student and teachers e-learning satisfaction. Three hundred and eighty -seven participates completed a survey questionnaire measuring their self-reported responses to six constructs tutor quality, perceived usefulness, perceived ease of use , coursed delivery, facilitation conditions, and course satisfaction. However, facilitating conditions was found to be a significant mediate or of perceived ease of use and satisfaction [26].

Ease of use is a tram that used to determine the simplicity of using a system, technology or anything else. It has been reported as many as fifty percent of adults, including first-year university student have some sort of computer-related phobia. Past research shows that computer anxiety influence how users perceive ease of use on information system. A survey methodology a approach was used in this study using 18 items for3 constructs (perceived ease of use, anxiety, and selfefficacy). Surrey data from 645 university students were analyzed. The findings show the importance of self-efficacy as a mediator between computers anxiety and perceived ease use of a learning management system [27]. A number of studies have indicates that the successful pedagogical use of technology depends on teachers attitudes and acceptance towards technology. Data were collected from 152 in - service teachers who education program in Hong Kong. The findings show that perceived ease of use become the sole determinant 
to the prediction of intention to use, Moreover, that computer self-efficacy and the perceived ease of use were able to explain $68 \%$ of the variance observed in users intention to use the e-learning system [28]. Zarqa university (Jordan) mode a study aimed to measure the impact of several antecedent factors (ease of use toward-learning, usefulness toward elearning, training on e-learning and trust of e-learning. The sample of (340) was selected from Zarqa University students. Results indicated the ease of use towered e-learning, usefulness toward e-learning, training on e-learning and trust of e-learning impacted attitude to use e-learning [29]. Based on above reviewed literature the following hypotheses are suggested which are represented in figure 1 the suggested research model:

H1: Ease of use will have a direct positive influence on intention of use e-learning.

$\mathrm{H} 2$ : Facilitating conditions will have a direct positive influence on intention of use of e-learning.

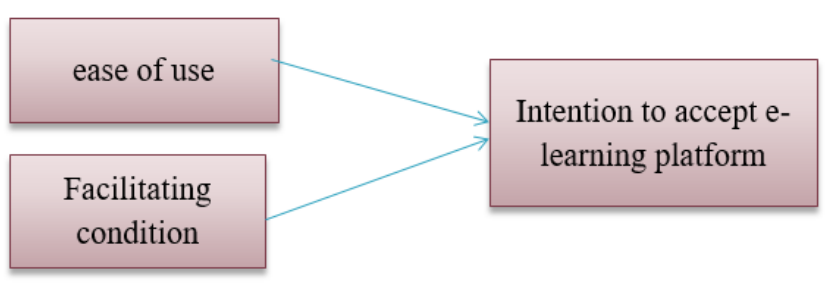

Figure 1: Study Model

\section{RESEARCH METHODS}

The study is aimed to determine the level of acceptance of e-learning specifically by the students as well as identifying the effect of ease of use and facilitating conditions on the intention of students to accept e-learning platforms.

Primary data was collected using online questionnaire, only 118 responses were valid for analysis. The measurement items for the variables were adopted from validated instruments[30], [31] and published articles and books used as a secondary source for getting data for this study.

An appropriate statistical analysis tests were used to check the instrument reliability (Cronbach's alpha )[32]-[34] and testing research hypotheses (multiple linear regression test)[35], [36]. To get this statistical test done the SPSS software was used.
IV. ANALYSIS

Table 1 reliability test

\begin{tabular}{lc}
\hline Variable & Cronbach's Alpha \\
\hline Ease of Use & 0.911 \\
Facilitating condition & 0.840 \\
Intention to accept e-learning platform & 0.815 \\
\hline
\end{tabular}

Multiple regression analusis used for hypotheses testing. Its results presented in the following tables $(2,3,4)$

\begin{tabular}{lccc}
\hline \multicolumn{3}{c}{ Table 2 Model Summary } \\
\hline Model & $\mathrm{R}$ & $\mathrm{R}$ Square & Adjusted R Square \\
\hline 1 & $.443^{\mathrm{a}}$ & .197 & .183 \\
\hline a. Predictors: (Constant), Facilitating Condition, Ease of Use
\end{tabular}

Table 3 ANOVA

\begin{tabular}{|c|c|c|c|c|c|c|}
\hline & Model & Sum of Squares & $\mathrm{df}$ & Mean Square & $\mathrm{F}$ & Sig. \\
\hline 1 & Regression & 31.778 & 2 & 15.889 & 14.076 & $.000^{b}$ \\
\hline & Residual & 129.807 & 115 & 1.129 & & \\
\hline & Total & 161.585 & 117 & & & \\
\hline
\end{tabular}

a. Dependent Variable: Intention to accept e-learning platform

b. Predictors: (Constant), Facilitating Condition, Ease of Use

Table 4 Coefficients

\begin{tabular}{|c|c|c|c|c|c|c|}
\hline & \multirow[t]{2}{*}{ Model } & \multicolumn{2}{|c|}{ Unstandardized Coefficients } & \multirow{2}{*}{$\begin{array}{l}\begin{array}{l}\text { Standardized } \\
\text { Coefficients }\end{array} \\
\text { Beta }\end{array}$} & \multirow[t]{2}{*}{$t$} & \multirow[t]{2}{*}{ Sig. } \\
\hline & & B & Std. Error & & & \\
\hline \multirow[t]{3}{*}{1} & (Constant) & 1.621 & .405 & & 4.003 & .000 \\
\hline & $\begin{array}{c}\text { Facilitating } \\
\text { Condition }\end{array}$ & .031 & .098 & .026 & .313 & .755 \\
\hline & EaseofUse & .426 & .081 & .440 & 5.247 & .000 \\
\hline
\end{tabular}

a. Dependent Variable: Intention to accept e-learning platform

Both ease of use and Facilitating condition, as shown in table $(2)(\mathrm{R} 2=0.197$.) has explained $(19.7 \%)$ of the variance in Intention to accept e-learning platform. Table (3) shows $\mathrm{F}$ test $(\mathrm{F}=14.076)$ is significant at $(\mathrm{P}<0.0)$. The results of utilized statistical test (regression analysis) shows that ease of use, see table (4), has a significant positive effect $(\beta=0.440$, sig. $=0.00)$ on Intention to accept e-learning platform. While. facilitating condition in the same table (4) has no significant effect $(\beta=0.026$, sig. $=0.755)$ on Intention to accept e-learning platform.

\section{DISCUSSION}

The study found the Ease of Use has a significant impact on the Intention to accept e-learning platform. This result is in agree with results of (Naim et al., 2019) which discloses that e-learning platform in Universities is ease of use for students. 


\section{International Journal of Engineering Applied Sciences and Technology, 2020 \\ Vol. 5, Issue 3, ISSN No. 2455-2143, Pages 45-49 \\ Published Online July 2020 in IJEAST (http://www.ijeast.com)}

The study found the Facilitating Conditions has no impact on the Intention to accept e-learning platform. This result is in disagree with results of (Allan et al., 2018) which discloses that there is a lack of facilitating conditions to adopt e-learning platform in Universities. However, universities should identify the user's needs and requirements for elearning system, Universities that implement e-learning should make the system flexible and essay to use by the users, Universities have to enhance their online-learning system performance, e-learning should facilitate all the conditions that fulfill user's satisfactions and acceptances, and the Internet infrastructure should be developed to cover wide distance.

The e-learning system is the future of education sector and the current issue of spreading of Covid-19 has proven the necessity of moving to online learning world to continue the learning process at any situations and conditions. So, the responsibility of universities and colleges that provide elearning platform for their student is identifying the users' needs that make them accept the modern way of learning. They have to keep in their minds all the factors that influence user's acceptance for e-learning system. For examples, ease of use and facilitating conditions that achieve the expectations and satisfactions of e-learning users.

\section{REFERENCE}

[1] H. Ibrahim, S. Karabatak, and A. A. Abdullahi, "A Study on Cybersecurity Challenges in E-learning and Database Management System," in 8th International Symposium on Digital Forensics and Security, ISDFS 2020, 2020, doi: 10.1109/ISDFS49300.2020.9116415.

[2] J. Lang and P. Kysel, "Conceptual modeling in elearning and its relation to the educational content quality," in ICETA 2019 - 17th IEEE International Conference on Emerging eLearning Technologies and Applications, Proceedings, 2019, pp. 465-470, doi: 10.1109/ICETA48886.2019.9040028.

[3] J. P. Vagarinho and M. Llamas-Nistal, "ProcessOriented Quality in e-Learning: A Proposal for a Global Model," IEEE Access, vol. 8, pp. 1371013734, 2020, doi: 10.1109/ACCESS.2020.2965619.

[4] L. Serhii, P. Volodymyr, K. Nataliia, and H. Andrii, "The conceptual foundations of the axiomaticdeductive strategy of e-learning course knowledge organization with high semantic quality," in IEEE 2019 14th International Scientific and Technical Conference on Computer Sciences and Information Technologies, CSIT 2019 - Proceedings, 2019, vol. 3, pp. 201-204, doi: 10.1109/STC-CSIT.2019.8929767.

[5] G. V. Verkhova and S. V. Akimov, "Qualimetric Models for E-learning Systems," in Proceedings of 2019 3rd International Conference on Control in Technical Systems, CTS 2019, 2019, pp. 192-195, doi: 10.1109/CTS48763.2019.8973357.

[6] B. Soukaina, J. El Bouhdidi, Y. El Younoussi, and J. M. Carrillo, "Web-Based Engineering
Education:Bibliometric Overview," in Proceedings 2019 International Conference on Intelligent Systems and Advanced Computing Sciences, ISACS 2019, 2019, doi: 10.1109/ISACS48493.2019.9068877.

[7] S. Hilmy, T. De Silva, S. Pathirana, N. Kodagoda, and K. Suriyawansa, "MOOCs Recommender Based on User Preference, Learning Styles and Forum Activity," in 2019 International Conference on Advancements in Computing, ICAC 2019, 2019, pp. 180-185, doi: 10.1109/ICAC49085.2019.9103376.

[8] Q. N. Naveed et al., "Relationship modeling for OSNbased E-Learning Deployment," 2020, pp. 1-7, doi: 10.1109/icetas48360.2019.9117275.

[9] A. Naim et al., "Ensuring interoperability of Elearning and quality development in education," in 2019 IEEE Jordan International Joint Conference on Electrical Engineering and Information Technology, JEEIT 2019 - Proceedings, 2019, pp. 736-741, doi: 10.1109/JEEIT.2019.8717431.

[10] A. Burdi, F. H. Chandio, M. S. Abbasi, F. A. Abbasi, and S. H. F. Naqvi, "Personalization, Screen design and E-learning System Acceptance: An Empirical Analysis," 2020, pp. 1-5, doi: 10.1109/icetas48360.2019.9117516.

[11] K. Souali, O. Rahmaoui, M. Ouzzif, and I. El Haddioui, "Recommending moodle resources using chatbots," in Proceedings - 15th International Conference on Signal Image Technology and Internet Based Systems, SISITS 2019, 2019, pp. 677-680, doi: 10.1109/SITIS.2019.00110.

[12] M. N. Alraja, M. A. Hussein, and H. M. S. Ahmed, "What affects digitalization process in developing economies? an evidence from SMEs sector in Oman," Bull. Electr. Eng. Informatics, vol. 10, no. 1, Feb. 2021, doi: 10.11591/EEI.V10I1.2033.

[13] M. N. Alraja, S. Hammami, and T. Alhousary, "Factors affecting e-government services adoption: Field study," J. Theor. Appl. Inf. Technol., vol. 78, no. $1,2015$.

[14] M. N. Alraja, S. Hammami, B. Chikhi, and S. Fekir, "The influence of effort and performance expectancy on employees to adopt E-government: Evidence from Oman," Int. Rev. Manag. Mark., vol. 6, no. 4, 2016.

[15] M. N. Alraja, "User Acceptance of Information Technology: A Field Study of an E-Mail System Adoption from the Individual Students' Perspective," Mediterr. J. Soc. Sci., vol. 6, no. 6 s1, pp. 19-25, Nov. 2015, doi: 10.5901/mjss.2015.v6n6s1p19.

[16] M. N. Alraja, B. F. Salim, M. A. Uddin, and M. Yousoof, "The adoption of internet banking: Clients' perspective in Oman," Int. Rev. Manag. Mark., vol. 6, no. 4, 2016.

[17] M. A. Hussein, H. Ahmed, and M. N. Alraja, "The adoption of information and communication technology by small and medium enterprises in Oman: 


\section{International Journal of Engineering Applied Sciences and Technology, 2020 \\ Vol. 5, Issue 3, ISSN No. 2455-2143, Pages 45-49 \\ Published Online July 2020 in IJEAST (http://www.ijeast.com)}

Case of Dhofar region," J. Bus. Retail Manag. Res. www.jbrmr.com A J. Acad. Bus. Retail Manag., vol. 11, no. 3, pp. 64-71, 2017, Accessed: 02-May-2017. [Online].

Available: http://www.jbrmr.com/admin/content/pdf/content_650 13_17-04-22-11-45-45.pdf.

[18] M. N. Alraja and B. Chikhi, "Perceived Factors affecting Customers Attitudes toward Electronic Shopping: an Empirical Study," Int. J. Econ. Res., vol. 12, no. 3, pp. 815-823, 2015, Accessed: 17-May2019. [Online]. Available: http://serialsjournals.com/abstract/51627_17.pdf.

[19] M. A. Uddin, F. Ahmar, and M. N. Alraja, "Eexaminations for management students in Oman," Int. J. Appl. Bus. Econ. Res., vol. 14, no. 1, 2016.

[20] F. D. Davis, "Perceived Usefulness, Perceived Ease of Use, and User Acceptance of Information Technology," MIS Q., vol. 13, no. 3, pp. 319-340, Sep. 1989, doi: 10.2307/249008.

[21] V. Venkatesh, M. G. Morris, G. B. Davis, and F. D. Davis, "Venkatesh et al (2003) User acceptance of information technology (1)," MIS $Q$., vol. 27, no. 3, pp. 425-478, 2003.

[22] M. N. Alraja, "The effect of social influence and facilitating conditions on e-government acceptance from the individual employees' perspective | Efekt Wpływu Społecznego Oraz Warunków Ułatwiających Akceptację E-Administracji Z Punktu Widzenia Indywidualnych Pracowników," Polish J. Manag. Stud., vol. 14, no. 2, 2016, doi: 10.17512/pjms.2016.14.2.02.

[23] P. J. Hu, P. Y. K. Chau, O. R. Liu Sheng, and K. Y. Tam, "Examining the Technology Acceptance Model Using Physician Acceptance of Telemedicine Technology," J. Manag. Inf. Syst., vol. 16, no. 2, pp. 91-112, Mar. 1999, doi: 10.1080/07421222.1999.11518247.

[24] J. W. Strijbos and A. Weinberger, "Emerging and scripted roles in computer-supported collaborative learning," Comput. Human Behav., vol. 26, no. 4, pp. 491-494, Jul. 2010, doi: 10.1016/j.chb.2009.08.006.

[25] H. Yevhen, "Methods of Assessment and Diagnosis of the Quality of Knowledge in E-Learning," J. Commun. Comput., vol. 12, pp. 286-296, 2015, doi: 10.17265/1548-7709/2015.06.002.

[26] J. L. Chen, "The effects of education compatibility and technological expectancy on e-learning acceptance," Comput. Educ., vol. 57, no. 2, pp. 15011511, Sep. 2011, doi: 10.1016/j.compedu.2011.02.009.

[27] K. Duncan, A. Kenworthy, and R. McNamara, "The Effect of Synchronous and Asynchronous Participation on Students' Performance in Online Accounting Courses," Account. Educ., vol. 21, no. 4, pp. 431-449, Aug. 2012, doi:
10.1080/09639284.2012.673387.

[28] A. Y. Akbulut and C. A. Looney, "Improving IS Student Enrollments: Understanding the Effects of IT Sophistication in Introductory IS Courses Background and Theoretical Development," 2009.

[29] D. A. Almajali, R. Masa'deh, and P. M. Al-Lozi, "Determinants of the Actual Use of E-Learning Systems: An Empirical Study on Zarqa University in Jordan," J. Soc. Sci., vol. 5, no. 2, pp. 172-200, Apr. 2016, doi: 10.25255/jss.2016.5.2.172.200.

[30] M. N. Alraja, S. F. Khan, B. Khashab, and R. Aldaas, "Does Facebook Commerce Enhance SMEs Performance? A Structural Equation Analysis of Omani SMEs," SAGE Open, vol. 10, no. 1, p. 215824401990018, Jan. 2020, doi: $10.1177 / 2158244019900186$.

[31] M. N. Alraja and M. A. Kashoob, "Transformation to electronic purchasing: an empirical investigation," TELKOMNIKA (Telecommunication Comput. Electron. Control., vol. 17, no. 3, pp. 1209-1219, Jun. 2019, doi: 10.12928/TELKOMNIKA.V17I3.9390.

[32] M. N. Alraja and N. M. M. Malkawi, "E-Business adoption in banking sector: Empirical study," Indian J. Sci. Technol., vol. 8, no. 27, 2015, doi: 10.17485/ijst/2015/v8i27/70739.

[33] M. N. Alraja and N. R. ALomiam, "THE EFFECT OF GENERAL CONTROLS OF INFORMATION SYSTEM AUDITING IN THE PERFORMANCE OF INFORMATION SYSTEMS :FIELD STUDY," Interdiscip. J. Contemp. Res. Bus., vol. 5, no. 3, pp. 356-370, 2013, Accessed: 03-Aug-2019. [Online]. Available: https://journal-archieves34.webs.com/356370.pdf.

[34] M. N. Alraja, M. M. J. Farooque, and B. Khashab, "The Effect of Security, Privacy, Familiarity and Trust on Users' Attitudes Towards the Use of IoT-based Healthcare: The Mediation Role of RiskPerception," IEEE Access, vol. 7, pp. 1-1, 2019, doi: 10.1109/access.2019.2904006.

[35] M. N. Alraja and N. R. Alomian, "THE EFFECT OF INFORMATION TECHNOLOGY IN EMPOWERMENT PUBLIC SECTOR EMPLOYEES: A FIELD STUDY," Interdiscip. J. Contemp. Res. Bus., vol. 5, no. 1, pp. 805-815, 2013, Accessed: 17-May-2019. [Online]. Available: https://journal-archieves32.webs.com/805-815.pdf.

[36] N. M. M. A. Malkawi, M. N. Alraja, and T. Alkhayer, "Information Systems Auditing Applied Study at Banks Listed in the Damascus Stock Exchange Syria," Eur. J. Econ. Financ. Adm. Sci., no. 21, p. 119, 2010, Accessed: 17-May-2019. [Online]. Available: http://connection.ebscohost.com/c/articles/52428507/i nformation-systems-auditing-applied-study-bankslisted-damascus-stock-exchange-syria. 